\title{
Agriculture :The Way To Inclusive Growth
}

\author{
Harneet Kaur \\ Government College For Girls Sector-11,Chandigarh
}

\begin{abstract}
India's agriculture sector continues to be the lifeline of its people and a key factor in the economy's overall productivity. Historically, India's agriculture growth has lagged growth in the overall economy. In fact, long-term average growth in agriculture has been close to $2 \%$. India's population has been growing at $1.4 \%$. Consequently, India has just managed to maintain its per capita growth in food and non-food crop production. Increasing profitability in agriculture through higher productivity has been an important goal in developing countries like India. It has become more relevant in recent years due to limited scope for expansion of arable land. Increasing yield to their technically highest level may be feasible, through adequate investment in infrastructure and technology i.e. irrigation, land development, storage, markets, etc. Besides appropriate pricing of inputs and outputs, availability of credit and extension services would facilitate access to available technology. like most other developing countries, India has predominantly been an agrarian economy, with agriculture sector contributing the largest share to gross domestic product (GDP) and employment. Under the colonial regime, Indian agriculture was geared towards the production of commercial crops (tea, coffee, rubber, cotton, etc.), while the food crops suffered from neglect. After independence, India depended heavily on imports of food grains as it inherited a stagnant, low-productivity, food-crop sector.

This paper analyses the dynamics of structural transformation of the Indian economy and major drivers of transformation, giving an overview of the past achievements and the future challenges in Indian agriculture, finally identifying the key policy issues and strategies to accelerate sustainable broad-based growth in the agriculture sector in the country.
\end{abstract}

Keywords: Sustainable Agriculture, Inclusive Growth, Dietary Consumption, Institutional Credit, Agricultural Price Policy.

Objectives

- Take a closer look at each link between agriculture and inclusive growth

- Role of agriculture in driving economic growth

- Role of agriculture in reducing poverty

- Role of agriculture in providing productive employment

- Discuss tools that can help country economists

- Encourage use of a broader set of existing tools

that can increase the focus of the analysis, sharpen the questions that need further investigating, and make progress on the second stage of diagnostics — on the "why" questions Why A

\section{Introduction}

At the time of independence, the share of agriculture in total GDP was more than 55 per cent and about 70 per cent of the population was dependent on the agriculture sector for their livelihood. In the postindependence era, stagnant production, low productivity, traditional technology, and poor rural infrastructure were the major challenges for the Government. Not surprisingly, food self-sufficiency became a key national policy goal. To achieve this goal, agricultural development received the highest priority and in the First Five Year Plan, about 17.5 per cent of the plan outlay was allocated to agriculture and about 22 per cent to irrigation, multi-purpose irrigation, and power projects. However, in the Second Five Year Plan, the emphasis shifted from labour-intensive agriculture and small scale production to large-scale capital-intensive heavy industry (Dantwala, 1986). Consequently, food grains production during the first three Five Year Plans remained stagnant, and India faced crisis in food production. The introduction of high yielding varieties (HYV) technology (commonly known as Green Revolution) in mid-1960s yielded spectacular results and the production of foodgrains increased from about 83.4 million tonnes in the triennium ending (TE) 1964-65 to 104.4 million tonnes in TE 1971-72 (GoI, 2012). Subsequently, the country, which was threatened by hunger and high dependence on imports as late as in mid-1960s, became one of the largest producers of many agricultural commodities such as rice, wheat, pulses, fruits and vegetables, etc., thus being self sufficient in staple foods. In aggregate, the food situation is quite favourable in the country and the problem of hunger is one of access and income distribution rather than shortages. Today, about 407 million people in India live below 
poverty line (GoI, 2009) and about 42 per cent of all children under 5 years suffer from malnutrition (HUNGAMA Survey Report, 2011). Increase in demand for food due to increasing population, rising income levels, and other demographic changes will require continuous increase in agricultural production. Agriculture and allied Sectors are critical sectors for inclusive growth of India, says India's Finance Minister P Chidambaram.

The agriculture growth rate for the 11th Plan has been targeted at 3.3 per cent as compared to 2.2 per cent achieved during the 10th Plan period, the Finance Minister added. He further said that we need sufficient agriculture production not only to meet our domestic requirement but also for exports. The Finance Minister was making his introductory remarks during his first pre-budget meeting with stakeholders from agriculture sector.

The foodgrain production during 2011-12 was 257.4 million tons and during the current financial year 2012-13 equally good foodgrain production is expected from the country.

\section{Agriculture the backbone of Indian economy and food security}

India is principally an agricultural country. The agriculture sector accounts for about $18.0 \%$ of the GDP and employs $52 \%$ of the total workforce. There is a continuous steady decline in its contribution towards the GDP, and the agriculture sector is loosing its shine and anchor position in Indian economy. The problems with which the Indian agricultural scenario is burdened in present times are many but this in no way undermines the importance of the sector, and the role it can play in the holistic and inclusive growth of the country. Agriculture is fundamental for sustenance of an economy as is food for a human being. It contributes significantly to export earnings and is an important source of raw materials for many industries. Its revival is being taken on priority, through various interventions at different levels, because of its potential in reducing poverty and food insecurity. The global experience of growth and poverty reduction shows that GDP growth originating in agriculture is at least twice as effective in reducing poverty as GDP growth originating outside agriculture. Agriculture is and will continue to be the engine of the national growth and development.

\section{Role of Agriculture in Growth}

- Two reasons why agriculture is considered central to growth

- It has a big share of GDP, and/ or

- It stimulates "structural transformation"- the process whereby resources move from low productivity sectors to higher productivity sectors.

- Two possibilities for structural transformation

- It can be driven by productivity improvements within the agricultural sector

- $\quad$ It can be driven by productivity improvement outside the agriculture sector

- There is no agreement which underlying process drives the structural transformation in general

- Without higher agriculture growth, India's 10\% economic growth target will be impossible to achieve. In addition, higher real incomes lead to higher food consumption, implying more pressure on demand. Historically, India's agriculture growth has lagged growth in the overall economy. In fact, long-term average growth in agriculture has been close to $2 \%$. India's population has been growing at $1.4 \%$. Consequently, India has just managed to maintain its per capita growth in food and non-food crop production.

Given such a precarious demand-supply position, one year of drought leads to food prices shooting up. This is what we are seeing at this time of the year. With growth in per capita incomes, the supply constraints will hit India even harder in the future..

What are the steps required? To begin with, agriculture has received only $7 \%$ of budgetary allocation in the recent past, down from about $20 \%$ in the 1980s. Considering the demand-supply imbalances and its importance as a source of livelihood for the rural economy, the budgetary allocation to agriculture should improve. On top of this, investment in the agriculture sector is $2.3 \%$ of gross domestic product. With an investment-to-GDP ratio in the country of more than $35 \%$, the Finance Minister has to engage the private and public sector in higher investments in agriculture. The long-term target should be close to $4 \%$.

The central government has limited scope to contribute to agricultural reforms through the budget as agriculture is largely a state subject. However, it can certainly take certain concrete steps. With the focus on long-term growth, the principal focus areas for increased outlay should be:

- Increased spending in agricultural research and farm extension practices to improve yield and production

- Better supply chain management in both procurement and distribution cycles through improvements in public distribution systems 
India's area under cultivation has remained constant since the 1970s. Hence, the two ways to improve productivity are: Yield management and irrigation. Performance on the yield front has been dismal. Yield growth in all major crops has been negligible. Over the last decade, wheat yields in the country have grown at $0.1 \%$ and rice at $1.3 \%$ per annum. Crops like pulses and sugar have actually witnessed a decline in yields to the tune of $0.2 \%$ and $0.4 \%$, respectively. With an increase in population, the yield per person has actually declined.

This does not bode well for the food security of the nation. The last time the country saw a productivity boost was during the "Green Revolution" and the adoption of hybrid crops. With such a huge population dependent on agriculture, India has every reason to push for agricultural research and disseminate such knowledge and practices to farms across the country. If the growth story in India is to be inclusive, farm productivity has to rise for income levels to increase. The research should focus on better farm practices, optimal use of fertilizers and pesticides, productive seed varieties (GM crops), multiple crops in the same land etc. Equally important is the dissemination of such knowledge to farmers.

On the irrigation front, the country should invest in building much more sustainable irrigation projects. These will not only help in easing drought conditions but also provide large- scale employment in the rural areas.

Another area which needs an urgent revamp is the supply chain. India's vegetable production increased by $5 \%$ this fiscal year but vegetable prices have increased a lot. This bears testimony to the disarray that exists in the current supply chain. A huge amount of produce is wasted in the procurement process due to a lack of timely action. Inadequate storage systems further compound the waste.

The nail in the coffin is the ineffective distribution system. Many states are not able to lift their allocated quotas due to inadequate storage facilities and instant ad-hoc cash requirements. With the developments made in the field of supply chain management and their successful adoption in the manufacturing sector, it is high time that better supply chain practices are implemented in the agricultural sector with the necessary investments made to facilitate this.

Better crop planning, demand estimation, transportation, warehousing facilities (both normal and cold storage) should be targeted and achieved. The government can also design tax incentives like tax holidays for setting up agricultural supply chains to boost private infrastructure development.

The government has taken measures in the last few budgets to increase credit disbursement to the farm sector, resulting in a tripling of lending in five years to about 2.5 lakh crores. It has also promoted crop insurance; however, crop insurance has generally seen dismal results in countries across globe. As a better risk management tool, the government should promote weather insurance primarily due to its transparency, objectivity and ease of administration.

These measures call for increased outlays. Agriculture needs to be accorded higher importance in the nation's development. Instead of spending on real assets, the government has doled out relief in terms of loan waivers. A large part of the subsidy given to the sector is in terms of fertilizer subsidies. The government is taking some stern and correct steps in the subsidy arena by linking subsidies to the nutrient content of fertilizer and reducing overall allocations. But such savings need to be diverted towards the development of agriculture. In increasing spending, the government needs to think beyond short-term populist measures and implement programs that would lead to the long-term growth of agriculture in the country.

India should have hard targets to increase productivity in the farm sector. At the same time, wastage should be removed. It would be a good idea to have a national distribution channel. However, for this, private sector capital and technology should be encouraged.

\section{Profiling the growth process}

Bosworth and Collins (2008) find:

- In both China and India, agriculture played a positive role but not a leading role in driving overall growth

○ In China, it was industry which contributed most to growth

- In India, the main growth driver was services

- In both countries, the reallocation effect was an important source of growth

- Gollin (2010) find similar evidence in a broader set of developing countries using the same technique

- The accounting framework which calculates the resource reallocation effect essentially as a residual

- Much like Solow residual in the growth accounting, it has well known problem of interpretation

- The decomposition exercise like this is good for understanding "what" happened but not "why" it happened 
- Is the growth in other sectors that pulls underutilized resources out of agriculture? or

- Is it productivity gains in agriculture that releases resources and make available to other sectors?

Understanding the process behind resource reallocation effects

Gardner investigates three alternative hypothesis

1. "Selective migration"

(poor farmers left agriculture faster than richer farmers)

2. "Labour market integration"

(growth in non-farm sector benefited low income farmers through greater off farm jobs and opportunities to leave farming altogether)

3. "Agricultural specific developments"

(e.g., changes in farm size, human capital, agricultural productivity at the state level)

\section{Policies for Raising Agricultural growth}

There are three goals of agricultural development. These are: (a) achieve 4\% growth in agriculture and raise incomes by increasing productivity (land, labour), diversification to high value agriculture and rural non-farm by maintaining food security; (b) sharing growth (equity) by focusing on small and marginal farmers, lagging regions, women etc.; (c) third is to maintain sustainability of agriculture by focusing on environmental concerns. What are the policies needed to achieve the above goals? There are basically seven factors which need focused reforms in the short and medium terms. These are: (a) price policy; (b)subsidies and investments; (c) land issues; (d) irrigation and water management (e) research and extension; (f) credit; (g) domestic market reforms and diversification. Institutions have to be developed in all these aspects .

\section{(a) Price Policy}

The major underlying objective of the Indian governments price policy is to protect both producers and consumers. Currently, food security system and price policy basically consists of three instruments: procurement prices/minimum support prices, buffer stocks and public distribution system (PDS). One criticism of procurement policy is that it is limited to few crops and few states. Our field visits to different states reveal the following farmers ${ }^{\text {ee }}$ perceptions about agricultural prices. The cost of cultivation is increasing due to increase in input prices. Particularly agricultural wages have increased due to National Rural Employment Guarantee Scheme (NREGS) in several states. They want to resort to mechanization due to labour shortages in peak season. Farmers respond to prices as shown by increase in yields of wheat in Punjab and other states with significant increase in MSP. Farmers have to undergo distress sales due to lack of procurement in states like Bihar, parts of UP, M.P. and Orissa. If rice production is to be shifted to Eastern region, rural infrastructure including procurement centres has to be improved. Pulses production can be enhanced in several states with higher MSP and procurement. Provision of electricity has to be raised in order to exploit ground water in Eastern region. In the context of globalization, tariff policy becomes important for agricultural commodities.

In other words, it is important to monitor exports, imports, global supply and demand and fix tariffs accordingly. There is a need to balance between producer prices and consumer prices by careful calibration of minimum support prices and tariff policy (import duties).

\section{b) Subsidies and Investments in Agriculture:}

One major reform needed in agriculture sector relates to reduction in subsidies and increase in investments. Agricultural subsidies are fiscally unsustainable and encourage misuse of resources, leading to environmentally malignant developments. There is trade-off between subsidies and investments. Public investment declined from $3.4 \%$ of agri.GDP in the early 1980 s to $1.9 \%$ in $2001-03$. At the same time subsidies increased from $2.9 \%$ to $7.4 \%$ of agri.GDP (GOI, 2007). Rise in public and private investment is crucial for enhancing agricultural growth. Fortunately, gross capital formation in agriculture has increased from $12 \%$ of agricultural GDP in 2004-05 to 14.2\% of GDP in 2007-08 (Table 4). Public sector investment has increased significantly during this period. However, we need 16\% agricultural GDP as investment in order to get $4 \%$ growth in agriculture. In this context, the announcement of Bharat Nirman programme in 2005 by the Government of India in order to improve agriculture and rural infrastructure is in the right direction. However, the pace of this programme has to be improved.

(c) Land Issues:

Some argue that small size of farm is responsible for low profitability of agriculture. Chinese and the experience of other East Asian countries show that it is not a constraint. On land market, the Report of the 
Steering Committee recommended the following. "Small farmers should be assisted to buy land through the provision of institutional credit, on a long term basis, at a low rate of interest and by reducing stamp duty.

At the same time, they should be enabled to enlarge their operational holdings by liberalizing the land lease market. The two major elements of such a reform are: security of tenure for tenants during the period of contract; and the right of the land owner to resume land after the period of contract is over" (GOI, 2007). Basically, we have to ensure land leasing, create conditions including credit, whereby the poor can access land from those who wish to leave agriculture. There are some emerging land issues such as increase in demand for land for non-agricultural purposes including special economic zones, displacement of farmers, tribals and others due to development projects. There is a need for careful land acquisition. Land alienation is a serious problem in tribal areas.

\section{(d) Irrigation and Water Management:}

Water is the leading input in agriculture. Development of irrigation and water management are crucial for raising levels of living in rural areas. Major areas of concern in irrigation are: decline in real investment, thin spread of investment, low recovery of costs, decline in water table, wastages and inefficiencies in water use and, non-involvement of users Both investment and efficiency in use of water are needed. Major areas of reforms needed in irrigation are: stepping up and prioritizing public investment, raising profitability of groundwater exploitation and augmenting ground water resources, rational pricing of irrigation water and electricity, involvement of user farmers in the management of irrigation systems and, making groundwater markets equitable (Rao, 2005). In a recent study, Shah et al (2009) indicate that the impact of the drought of 2009 is expected be less severe than the drought of 2002 due to ground water recharge in the last few years. Ground water can be exploited in a big way in Eastern region. Watershed development and, water conservation by the community are needed under water management. New watershed guidelines based on Parthasarathy Committees recommendations were accepted by the Central Cabinet in March 2009. The implementation has to be stepped up in order to obtain benefits in rainfed areas. National Rainfed Area Authority has big responsibility and, water conservation by the community are needed under water management.

\section{(e) Credit:}

According to the expert group on Financial Inclusion (GOI, 2008) only $27 \%$ of farmers have access to institutional credit. It is true that there have been some improvements in flow of farm credit in recent years . However, the Government has to be sensitive to the four distributional aspects of agricultural credit. These are: (a) not much improvement in the share of small and marginal farmers; (b) decline in credit-deposit (CD) ratios of rural and semi-urban branches; (c) increase in the share of indirect credit in total agricultural credit and; (d) significant regional inequalities in credit.

\section{Few Other Issues Emerging Challenge: Climate Change}

Climate change is a reality. India has reasons to be concerned about climate change. Vast majority of population depends on climatic sensitive sectors like agriculture, forestry and fishery for livelihood in the country. The adverse impact of climate change in the form of declining rainfall and rising temperatures and thus the increased severity of drought and flooding, would threaten food security and livelihood in the economy. For example, rise in temperature would affect wheat yields. India has prepared a document namely the National Action Plan on Climate Change. It provides a direction for changes at the national level in policy, planning and public-private partnerships and lays out a global vision for modifying longer time trends for sustainable development. Successful adaptation coupled with mitigation holds the key to food security and livelihoods for the 21 st century and beyond in India.

\section{Equity in Agriculture}

Regional Disparities: Growth rates in agriculture SDP were high for many states during the period 1984/85 to 1995/96. However, growth decelerated in all the states except Bihar during the period 1995/96 to 2004/05 (GOI, 2007). The deceleration is the highest in the states with greater proportion of rain-fed areas (Gujarat, Rajasthan, M.P., Karnataka and Maharashtra). Recent experience, however, shows that Gujarat recorded the highest growth of around 9 per cent during 2000/01 to 2007/08 (Gulati, 2009). During this period, six states viz., Gujarat, Rajasthan, Himachal Pradesh, Andhra Pradesh, Chattisgarh and Bihar recoded more than $4 \%$ growth per annum. Public investment in infrastructure like irrigation, power, roads, watersheds, check dams, technology like BT cotton and diversification in agriculture played crucial roles in raising agricultural growth in Gujarat. Other states can learn from the experience of Gujarat. There is a need to shift rice cultivation to Eastern region from Punjab and Haryana for growth, equity and environment reasons. In order to encourage the States to invest more towards agriculture and allied sectors and to achieve $4 \%$ growth in agriculture, the 
government launched the Rashtriya Krishi Vikas Yojana (RKVY) in 2007-08 with an outlay of Rs.25,000 crores for the 11th Five Year Plan. The scheme requires the States to prepare District agriculture plans and provides adequate flexibility and autonomy to State governments. The States should make use of this scheme to improve the agriculture sector.

\section{India's agriculture growth to remain positive for 2012-13}

India's agricultural growth for the 2012-13 is expected to be positive, largely on the back of normal monsoon prediction. The Gross Domestic Product (GDP) growth in the agricultural sector is forecast at 3\% for coming year, according to the National Council of Applied Economic Research (NCAER).

India's agricultural growth for the 2012-13 is expected to be positive, largely on the back of normal monsoon prediction. The Gross Domestic Product (GDP) growth in the agricultural sector is forecast at 3\% for coming year, according to the National Council of Applied Economic Research (NCAER).

India's agricultural growth for the past three has remained in the positive regime and it is expected to continue for coming years too. The positive prediction by NCAER is on the basis of following reasons: Normal monsoon forecast from the Indian Institute of Tropical Meteorology for 2012-13. Surplus food grain stock is expected for next year on the back of record harvest in 2011-12 and food grain stocks with the government may reach 75 million tons by July end. But presently, one of the major problem faced by India is lack of proper storage facility for storing agricultural produces. The inflation rate of the country has dropped but the price hike in milk, crude oil, eggs, meat and oilseeds creating problems for the policy makers.

\section{Conclusion}

- $\quad$ The three key roles agriculture can play in promoting inclusive growth - $\quad$ stimulating economic growth, reducing poverty, and creating employment

- Ways in which agriculture can contribute to or pose a challenge to achieving more inclusive growth through any of these links vary

- depends on country context, and within country over time

- Descriptive tools are useful for "what" question, but additional tools are needed to address "why" questions

- Some of the "why" question tools we've discussed: binary or categorical regressions, convergence (ECM) models, spatial regressions

\section{References}

[1]. Acharya, S.S. (1997), “Agricultural Price Policy and Development : Some Facts and Emerging Issues” Indian Journal of Agricultural Economics, Vol.52, No.1

[2]. Alagh, Y.K. (2006), "Indian Economic Strategies After Doha" in Radhakrishna, R, S.K. Rao, S.Mahendra Dev and K.Subbarao (2006 eds.), India in a Globalising World: Some Aspects of Macroeconomy, Agriculture and Poverty, Essays in honour of C.H. Hanumantha Rao, Academic Foundation

[3]. Bhalla, G.S. (1995), "Globalization and Agricultural Policy in India”, Indian Journal of Agricultural Economics, Vol.50, No.1

[4]. Bhalla, G.S. (2006), "Agricultural Growth and Regional Variations", in R.Radhakrishna, S.K. Rao,

[5]. S.Mahendra Dev and K.Subbarao (eds.), India in a Globalising World: Some aspects of Macro economy, Agriculture and Poverty, Essays in honour of Prof. C.H. Hanumantha Rao, Academic Foundation, New Delhi

[6]. Bhattacharya, B.B. (2003), "Trade Liberalization and Agricultural Price Policy in India Since Reforms", Indian Journal of Agricultural Economics, Vol.58, No.3

[7]. Chadha, G.K. (2009), “Agriculture and Rural Industrialization in India, Recent Developments and

[8]. Future Concerns" in Rao, N.C. and S.Mahendra Dev (eds.,2009) India: Perspectives on Equitable Development, Academic Foundation

[9]. Dev, S. Mahendra (2008), Inclusive Growth in India, Agriculture, Poverty and Human Development,

[10]. Gulati, Ashok (2009), "Emerging Trends in Indian Agriculture: What can we learn from these?"

[11]. Joshi P K and A. Gulati (2003), 'From Plate to Plough: Agricultural Diversification in India', Paper presented at the Dragon and Elephant: A Comparative Study of Economic and Agricultural Reforms in China and India", New Delhi, India, March

[12]. Ahluwalia, Montek S (2011). "Prospects and Policy Challenges in the Twelfth Plan," Economic and Political Weekly,

[13]. Bhalla, G S and Singh, Gurmail (2009). "Economic Liberalisation and Indian Agriculture: A Statewise Analysis," Economic and Political Weekly, 44(52)

[14]. CSO (2011). Gross State Domestic Products and Net State Domestic Product (2004-05 Series), Central Statistics Office (CSO), Ministry of Statistics and Programme Implementation, Govt. of India, New Delhi, August.

[15]. CSO (2011a). National Accounts Statistics 2011 and Earlier Issues, Central Statistics Office (CSO), Ministry of Statistics and Programme Implementation, Govt. of India, New Delhi, August. 